\title{
Situation of agricultural policy in the sector of agave mezcalero in Mexico, theory and reality
}

\section{Situación de la política agrícola en el sector agave mezcalero en México, teoría y realidad}

VÁZQUEZ-ELORZA, Ariel†*, SANCHEZ-OSORIO, Ever, HERNÁNDEZ-LÓPEZ José de Jesús, CASTAÑEDA-BERNAL Xóchitl Yolanda

Centro de Investigación y Asistencia en Tecnología y Diseño del Estado de Jalisco A.C

ID $1^{\text {st }}$ Author: Ariel, Vázquez-Elorza / ORC ID: 0000-0002-6710-8935, SNI: 35737, CVU CONACYT ID: 169076

ID $1^{\text {st }}$ Coauthor: Ever, Sánchez-Osorio / ORC ID: 0000-0002-4003-5553, SNI: 68400, CVU CONACYT ID: 209681

ID $2^{\text {nd }}$ Coauthor: José de Jesús, Hernández-López / ORC ID: 0000-0003-0507-6816, CVU CONACYT ID: 42251

ID $3^{\text {rd }}$ Coauthor: Xóchitl Yolanda, Castañeda-Bernal / ORC ID: 0000-0001-8921-1004, CVU CONACYT ID: 164155

DOI: $10.35429 /$ EJROP.2019.8.5.13.22

Received March 14, 2019; Accepted June 15, 2019

\begin{abstract}
This research aims to examine the characteristics of the sector mezcalero in Mexico. The analysis was qualitative, of observation about the organization and quantitative of the information in the territories. The activity responds to the importance of generating income, strengthening the wealth of cultural, ancestral traditions and experiences of indigenous people. The agricultural policy undertaken by the Mexican state in the value chain should include coordinated actions among the three areas of government to boost productivity.
\end{abstract}

Agave, Mezcal, Agricultural policy, Production, organization

\begin{abstract}
Resumen
Esta investigación tiene como objetivo examinar las características del sector mezcalero en México. El análisis que se presenta es bajo una metodología mixta, por una parte, se presenta una parte cualitativa por medio de la observación sobre la organización, así como un apartado cuantitativo de la información de los territorios. La actividad responde a la importancia sobre la generación de ingresos, fortalecimiento de la riqueza de tradiciones culturales, ancestrales y experiencias de pueblos indígenas. La política agrícola que emprenda el Estado mexicano en la cadena de valor debe incluir acciones coordinadas entre los tres ámbitos de gobierno para potenciar la productividad.
\end{abstract}

Agave, Mezcal, Política agrícola, Producción, Organización

\footnotetext{
* Correspondence to Author (email: avazquez@ ciatej.mx)

$\dagger$ Researcher contributing first author.
} 


\section{Introduction}

The production in Mexico of distillates of mezcalero agaves is mainly located in rural communities formed mostly by indigenous and peasants who face socio-economic problems linked to marginalization and social inequality, as evidenced by relating the elaborated municipal Social $\mathrm{Lag}^{1}$ (RZ) by the National Population Council (CONAPO, 2015), the Indicators generated by the National Council for the Evaluation of Social Development Policy (CONEVAL, 2015) and information on the mezcalera production of the Agrifood and Fisheries Information Service, and the Secretariat of Agriculture, Livestock, Rural Development, Fisheries and Food (SIAPSAGARPA, 2015).

There are 963 municipalities that have the Denomination of Origin (DO), and 44 more that are in the process of Denomination. From the first, in the country, it is evidenced that 128 municipalities have a very high RZ, 349 high RZ, 274 medium RZ, 211 low RZ, 41 very low RZ and, 4 do not have information. Namely, the majority of dwellings dedicated to the production of agave mezcalero in Mexico and located in rural locations are characterized by maintaining levels of poverty, lack of access to services, low levels of competitiveness and, on exploitation of wild agaves given the high demand for agave pineapples according to the characteristics and market structure of the byproducts.

\footnotetext{
${ }^{1}$ The Social Delay Index "is a weighted measure that summarizes four indicators of social deprivation" that include "access to health services, housing quality, basic housing services and household assets" CONEVAL (2015). Baseline indicators are: 1 . Percentage of population aged 15 years or more illiterate. 2. Percentage of population aged 6 to 14 who do not attend school. 3. Percentage of population aged 15 years and over with incomplete basic education. 4 . Percentage of population without right to health services. 5. Percentage of dwellings with dirt floor. 6. Percentage of homes that do not have a toilet or toilet. 7. Percentage of homes that do not have piped water from the public network. 8. Percentage of homes that do not have drainage. 9. Percentage of homes that do not have electricity. 10. Percentage of homes that do not have a washing machine. 11. Percentage of homes that do not have a refrigerator.
}

In the particular case of the mezcalero sector, it currently stands out with the existence of 493,750.88 square kilometers $(\mathrm{km} 2)$ of territory in the country that has the Denomination of Origin (hereinafter DO), composed of 963 municipalities distributed in the following entities: Oaxaca (570) representing $56.6 \%$ of the national total; Guerrero $(81,8 \%)$ Durango (39, 3.9\%), San Luis Potosí (58, 5.8\%), Zacatecas (58, 5.8\%), Guanajuato $(2,0.2 \%)$, Tamaulipas $(11,1.1 \%)$, Michoacán (29, 2.9\%), Puebla (115, 11.4\%).

In addition, there are three entities in the process of DO that are Aguascalientes (6, $0.6 \%)$, State of Mexico $(15,1.5 \%)$ and Morelos $(23,2.3 \%)$. It is important to note that the municipalities in the states of Aguascalientes, State of Mexico and Morelos joined the DO in August 2018.

The value chain ${ }^{2,3}$ refers to those actors involved in the agave and mezcal sector, including from suppliers to the final consumer. On the other hand, the productive chain is limited to the primary sector and agents that seek the transformation and commercialization of mezcal.

\begin{abstract}
${ }^{2}$ The productive chain is different from the value chain. According to Porter (1986), the generic value chain incorporates support activities such as the firm's infrastructure, human resources management, technology development and procurement; as well as internal logistics, operations, external logistics, marketing, sales and services (Porter, 1986, p. 38). On the other hand, the Red America establishes that "The concept of Productive Chain is linked to the spontaneous relationship between actors involved in economic relations and provision of goods and services from primary production to the arrival to the consumer" (Redameerica, 2018).

3 According to Van Der Hieden (2004) cited by FAO (2011), the production chain is made up of "interrelated actors and a succession of production, transformation and marketing operations of a product in a given environment $[\ldots]$, in addition, there is very little trust and even information is not shared among the actors "(FAO, 2011, p.9). On the other hand, Holmlund and Fulton (1999, cited by FAO, 2011); They point out that "Value chains are demand-oriented productive chains, which involve differentiated and specialized products, coordination relationships and clearly defined rules of the game for their management, higher income in the markets, close interdependence between actors" (FAO, 2011, p.9). Unlike the productive chain, in the value chain the actors share collaboration, risks with strong relationships of trust.
\end{abstract}

VÁZQUEZ-ELORZA, Ariel, SANCHEZ-OSORIO, Ever, HERNÁNDEZ-LÓPEZ José de Jesús, CASTAÑEDA-BERNAL Xóchitl Yolanda. Situation of agricultural policy in the sector of agave mezcalero in Mexico, theory and reality. ECORFAN Journal-Republic of Paraguay. 2019. 
In this context, there is undoubtedly a need to have more productive Economic Units (PEU) more productive mixers and with higher incomes, yields, but, above all, with a greater insertion on their social valorization; coupled with a reduction in transaction costs. Undoubtedly, this reality is linked to relevant factors to consider in the design of public policies, such as: sustainable use of biodiversity, strengthening of idiosyncrasy, and traditional and traditional cultural factors existing between the rural and indigenous population.

The strategic indicators of the rural and fisheries sector in Mexico (2012), obtained by FAO (2012 a; 2012 b), show the existence of $5,424,430$ rural economic units (EBUs) established in urban locations, but especially in rural areas. Among the federal entities that stand out can be mentioned Oaxaca with 661,333 UER, Guerrero $(514,581)$ and Chiapas $(500,727) .47 .67 \%$ of the EBUs are located in the strata classified with low assets and with a high marginality; $56.64 \%$ of the units have primary education, $13.29 \%$ with secondary, $4 \%$ with high school, $1.02 \%$ with a technical career, $13.82 \%$ have a university and only $0.18 \%$ have a postgraduate degree. In the case of the production of agave mezcalero the representation is greater in the states of Oaxaca and Guerrero in the Southeast South of the country.

The makers of the design and implementation of public policies should consider multifactorial aspects of the social problems facing the sector, in addition to those related to productive improvement, public management and institutionality that benefits or harms the national agave mezcal sector. To contextualize the productive importance of the sector, some important characteristics are listed below.

\subsection{Agave Mezcal Value Chain problem tree}

Among the main problems in the value chain is the lack of a vision of entrepreneurship to boost business in the Productive Units that inhabit the marginalized areas. However, it is important to keep in mind that cultural, regional factors and the relationship between producers play a preponderant role in localities and states with DO.
The problem tree is related to regions where there is a strong presence of ethnic groups (Zapotec, Chichimecas, Mixtecas, Nahuatl, among others) that affect the development of productive activities where they do not necessarily incorporate the element of profitability as the main incentive for mezcal production, but is linked to the status that symbolizes in the community belong to the production chain or be master mezcalero.

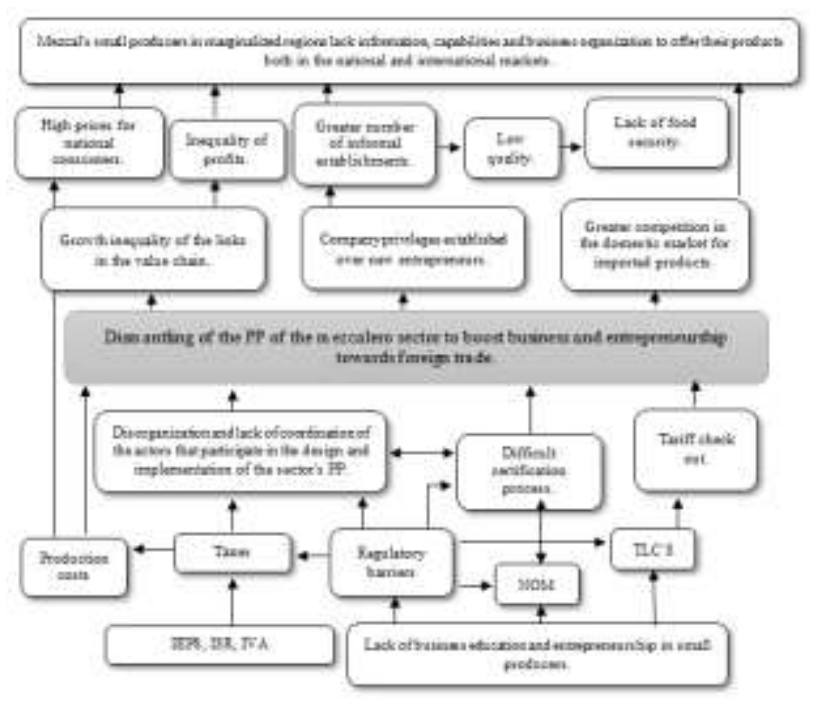

Figure 1 Agave Mezcal Value Chain problem tree Source: Alvarado, Vázquez, Contreras y Carmona (2017)

In the field work carried out in rural producing areas, there has been a disarticulation between the institutions to create synergies and increase local productions, such as: financing accessible for planting, production, increase in certifications for small mezcal producing units in the localities with DO, conversion programs for wild agave exploited areas, access to commercialization channels among small producers to increase their profit margins, reuse of wastes and compounds obtained for the manufacture of natural products, cosmetics, inulins, coal, paper, eco blocks, flavored distillates, among others.

In spite of the great territorial extension that the DO has in the country with planting and production potential, only $16.30 \%$ of the municipalities made plantings in 2016; that is, 158 municipalities of 963 , according to data from SIAP-SAGARPA, (2016). This reality demonstrates a weak link (lack of coordination) between productive actors and public policy strategies in the federal entities to encourage the sustainable use of agaves as a measure to meet local and international demand. 
This leads to obtaining some negative effects such as the increase in raw material, a situation that has occurred in recent years, having as one of its main consequences, high prices for mezcal production.

As a result of the lack of productive planning in the sector, at a national level, small producers have suffered more from the high prices resulting from the cost of harvested agave pineapple, this has encouraged producers and private institutions located in "Without Denomination of Origin" (SDO) municipalities to plant agaves; in 2016, seven municipalities that carried out this primary production activity were registered.

The agave mezcalero sector is no stranger to the reality described by the indicators obtained by FAO (2012 a, 2012 b). This problem is increased in the absence of efficient and effective government programs to potentiate agribusiness, sustainable use of agaves, training and specialization in production, the management of financial budgets to increase profitability, the use of agricultural waste to obtain products with added value, among others.

The Economic Commission for Latin America (ECLAC, 2017), Inter-American Institute for Cooperation on Agriculture (IICA) and the Food and Agriculture Organization of the United Nations (FAO) noted that Mexico, as well as other Latin American countries and the Caribbean (LAC) needs to accelerate the step to achieve the Sustainable Development Goals (SDGs) proposed in the 2030 Agenda, mainly on three main fronts: policies aimed at improving crop productivity; policies to reduce inequality within agrifood chains, facilitating an equitable distribution of benefits among all actors; and policies aimed at developing systems based on agriculture with greater resilience and less impact on natural resources and climate (CEPAL, FAO, IICA, 2017, pp. 204-205).

After the commercial and economic opening of Mexico in the 1990s, the domestic agricultural market generated structural changes both in the supply and in the demand for products and services with the world.
The mezcal production chain is no exception and it has been observed that in recent years the international demand has increased, generating an increase in consumption of wild agaves. In contrast, the need to increase competitiveness and strengthen the Value Chain is evident; namely, the Annual Average Growth Rate (TCMA) of the volume of the national primary production of agave mezcalero between 2010-2016 was negative with a $10.2 \%$ reduction annually.

This reality of the mezcalera activity intensifies the unsustainable use in the sector whose consequences can be transferred towards social and economic problems in the municipalities, mainly, in those that have the denomination of origin (DO). For the development of this work it was necessary to analyze qualitative, quantitative variables and experiences of field work carried out within the framework of the Agave Mezcal Project PN1406-2015 CONACyT-CIATEJ.

\section{General considerations on public policy in agave and mezcal}

In Mexico, agricultural, environment and rurality policies are sectorized in the Ministry of Agriculture and Rural Development (SADER), Ministry of Environment and Natural Resources (SEMARNAT), Secretariat of Rural Development (SEDESOL); In addition, the Ministry of Finance and Public Credit (SHCP) that controls the economic policy (financial, fiscal and expenditure).

There are also decentralized, decentralized and parastatal institutions that participate directly and indirectly in activities that seek to boost the agricultural sector from different fronts, including: the National Council of Science and Technology (CONACyT), with its Public Centers of Research (CPI's), in the line of work on environment, health and food; Chapingo Autonomous University (UACh); Antonio Narro Autonomous Agrarian University (UAAAN); National Forest Research Institute; Agricultural and Livestock (INIFAP) and Regional Centers, Graduate College (COLPOS); PRODUCE Foundations; National Autonomous University of Mexico (UNAM), among others. 
After investigating the reports on the sector, it can be observed that unfortunately there is no accessible global repository in the country that shows all the evidence and results obtained towards the productive chain between the different institutions. The generation of information, knowledge, cultural practices, innovation are scattered. On the other hand, there are research studies (such as other documents such as theses, theses, etc.) available to society through electronic means in various universities, research centers, universities and public and private institutes in the country in a disjointed manner. In the absence of interinstitutional coordination guidelines in the federal and state public administration for the agave and mezcal sector, a comprehensive system that offers transparency on the materialization of public resources allocated to the chain in terms of plant propagation, packages, is lacking Technological production, profitability, updated information on the number of producers in the localities, certifications and transaction costs in the value chain in agave and mezcal, among other actions.

Continuing with the context on the legal precepts of the Mexican state for development in the primary sector, it is pointed out that through the executive branch the guidelines of agricultural policy are established on the components that will be operationalized in the different areas of government (which are commonly carried out from top to bottom or top down) within the framework of administrative, political and economic centralism. Article V of the Federal Planning Law establishes that these must be built on "The basis for participation and consultation of society, including indigenous peoples and communities, through their representatives and authorities, in the preparation of the Plan and programs referred to in this Law "; (Federal Planning Law) whose result is the National Development Plan (PND) that represents the articulating axis of the public policies of the sexennium. On the other hand, the Federal Public Administration Law (LCF) establishes in Article 35 section I that the SADER corresponds to "Formulate, conduct and evaluate the general policy of rural development, in order to raise the standard of living of families living in the field, in coordination with the competent agencies "(LCF, p. 25).
In addition, the PND (2019-2024) points out in the Economy component Boosting economic recovery, the internal market and employment; as well as food self-sufficiency and rescue of the PND field (pp. 51-55).

In recent years, the study of public policies has represented an important tool for government actors in the executive and legislative power to generate efforts to solve national problems, mainly in the social and economic fields. Anderson (2006) defines the Policy as "a relatively stable and intentional course of action followed by an actor or group of actors when dealing with a problem or situation of interest" (p. 6). For its part, Tamayo (1997), describes that public policies "are the set of objectives, decisions and actions carried out by a government to solve the problems that citizens and the government themselves consider a priority at a given time" (p. 281). It is important to point out that the great public policy scholars have developed methodologies with the purpose of adapting and replicating in other countries such as Mexico, however, these actions are generally carried out in the government spheres through federal programs; in contrast, its applicability at a local and regional level with agricultural municipalities that remain with high levels of poverty and marginality is still distant.

On the other hand, there are several factors that have influenced the increase in the price of the Mezcal spirit drink, among them stand out: the accelerated increase in national and international consumption, reduction in the supply of wild agaves as a result of a lack of planning for increase the area planted in the main fields of production, changes in the climate that have affected the appearance of new diseases and attack of insects in the plantations. $^{4}$

According to the field work carried out, it is evident that small producers lack adequate information, knowledge and infrastructure to reach higher levels of negotiation and compete with certified producers, achieving high prices, processes and products to export.

\footnotetext{
4 Until now, Agave mezcalero does not have the federal strategic product range in the Agromercados Social y Sustentables (AMSYS) Program whose purpose would be to offer producers incentives to market; certify; train and technical assistance, among other benefits given to the country's strategic products.
}

VÁZQUEZ-ELORZA, Ariel, SANCHEZ-OSORIO, Ever, HERNÁNDEZ-LÓPEZ José de Jesús, CASTAÑEDA-BERNAL Xóchitl Yolanda. Situation of agricultural policy in the sector of agave mezcalero in Mexico, theory and reality. ECORFAN Journal-Republic of Paraguay. 2019. 
In addition, it is essential that society and consumers, mainly value the culture, traditions and intangible aspects offered by an artisanal and ancestral product. In this way, the process and design of public policies should be aimed at solving productive, socio-economic and business problems, always with respect to the environment and the place of the plant and drink within the culture of small producers. Inequality and diversity among localities producing agave mezcalero force agrifood public policies to treat unequals in the social development of the vulnerable population involved in the value chain. That is, existing heterogeneous problems cannot be treated the same.

Undoubtedly, Oaxaca is the state in the country that is an example in the production of agave mezcalero. Therefore, it is relevant to know what are the actions undertaken so far. According to the Master Plan of the Maguey Mezcal Product System in the state of Oaxaca (PRSPMMO, 2014, p. 10), it considers that the chain is made up of the following link levels: a) agave collector, firewood collector; b) grower producer, B) producer of maguey, c) packer, d) marketer, e) at other levels are carriers, input supplier, COMERCAM, service providers, federal, state government, research institutions, Committees Product Systems and other actors such as the National Institute of Industrial Property (IMPI), Federal Consumer Office (PROFECO), among others.

In fieldwork, the existence of various marketing channels has been confirmed with the presence of imperfect markets where the large mezcal producing companies, located mainly in Santiago Matatlán, commonly known as the "Mezcal World Capital", dominate due to the large volumes that produce and commercialize, in addition to the presence of large marketers or brands that come to buy mezcal in bulk. In contrast, there are also groups of small producers with weak formal linkages with the national market, insufficient information on prices, market, potential niches, marketing, certification processes to export, lack of technological packages to increase production, collection centers, transport to distribute mezcal, manuals of good process practices, among others. This reality hinders the development and growth of their economic productive units.
Small producers seek to get closer to the final consumer and reduce intermediary to increase profit margins in marketing. The above is generated by the lack of marketing mechanisms, economic incentives, asymmetry of information on prices in by-products, among others. As an organizational measure to counteract this situation in recent years, advances have been developed, such as the constitution of the Association of Master Teachers (AMM) whose purpose is to increase their access and information capabilities for the sale of their products at prices more competitive; as well as helping each other to generate collaboration networks and mass sales as much as possible (Personal communication).

The AMM is characterized in that it is directed mainly by a group of women from the regions of Villa Sola de Vega, San Baltazar Chichicapam and Miahuatlán de Porfirio Díaz, in Oaxaca. When small producers join, they increase their negotiation skills, mainly because they go to national and international fairs to promote their products considering the differentiation that exists in each of them. Given this scenario, it will be very important to generate public policies that incorporate social and solidarity economy, cooperatives, collaborative work, clusters, fair trade, mainly. However, there is also the theory of rational choice "that incorporates the application of notions of economics (and to some extent, from mathematics) to the analysis of the way in which the selfless behavior of individuals can influence the process of policies" (Hill 2005, p. 51).

\subsubsection{Value chain structure}

Although the PRSPMMO (2014) establishes a descriptive platform for the value chain of mezcal agave, it is important to note that in the country it is diversified and structured depending on the federative entity where the analysis is carried out; In general, it is very heterogeneous.

The value chain is in a development process due to its heterogeneity and the diversity of actors involved, according to the state under study, since each operates in very particular ways. 
In this case, it can be established that the link in order of political - administrative hierarchy corresponds to the executive branch with the federal, state and municipal government that include institutions related to the operation of policies and programs aimed at strengthening the primary sector. The main links in the value chain that have been identified in the value chain can be distinguished in Figure 2.

From an external scope, although directly related to the local and federal power relations, the agriculture and innovation commissions of the legislative branch where the budgets are designed and programmed to be exercised in the strategic sectors. Here the guidelines and legislative rules to operate the actions and resources in the case of the executive branch are established. Undoubtedly, the Product Systems of Maguey Mezcal in the states of the Republic seek to represent producer organizations in general. However, there are various types of alliances between them, which interact individually or in groups as appropriate.

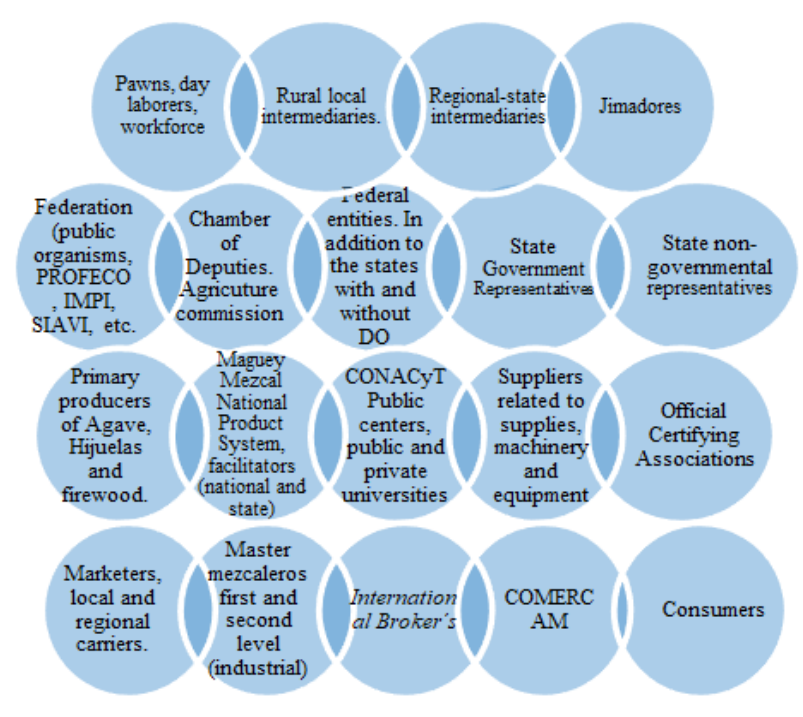

Figure 2 Links of the mezcal agave value chain Source: Own elaboration based on field work

In the primary sector, it is the wood producers, nurseries that offer important and necessary raw materials in the primary and industrial processes. Most of them are part of the same families that live in the producing localities. The problem that small producers incorporate is also related to the lack of knowledge about tax requirements, export permits, certifications before COMERCAM and even lack registered trademarks before IMPI.
For these reasons they are forced to sell their production in bulk without having knowledge of the final destination of the consumption of their product, nor the price at which it ends up selling. Due to lack of financial resources, they do not have the conditions to place their product on a shelf in convenience stores.

In the case of national and international marketers, there is a hoarding of the production of small mezcal producers in marginalized regions, this reality is frequent, to subsequently place the product in private state stockpiles and be sold in cities or areas Metropolitan consumption. In this context, public policies should be aimed at clearing unwanted or convenient practices that are developed, and instead improve flows by reducing intermediaries and increasing marketing margins for the primary sector.

According to the COMERCAM report (2017), in Mexico there were a total of 2.0 million liters (mill / 1) for the export market and 1.8 million / 1 for the national market. Of this total, approximately 2.4 million $750 \mathrm{ml}$ bottles were packaged in the country. Considering the taxes generated in the sector, 626.5 million pesos in taxes would have been obtained in the whole sale of mezcal. It should be noted that the state of Oaxaca contributed $65.1 \%$ in 2016 , that is, if there were a distribution of taxes to the producing areas, it would have to exercise an amount of 408 million pesos which would enhance the deficiencies that exist in the sector through the implementation of effective, efficient and economic PP. In reality, a focused policy that contains this amount of resources has not been identified to guide them to the most unprotected areas.

With the coordination of the Center for Research and Assistance in Technology and Design of the State of Jalisco, a Mexican thematic Network was established on the integral sustainable use and biotechnology of agaves -AGARED_ with the purpose of promoting research, linking and research teams of diverse disciplines (biotechnology, process innovation, food, sociology, administration, economics) and propose solutions to the sector. 
To date, academics from various institutions in the country, public and private, as well as producers and entrepreneurs are integrating, trying to define axes of action for prospective purposes to participate in the solution of several of the problems stated in the tree described above. Likewise, the Center for Research and Assistance in Technology and Design of the State of Jalisco A.C. (CIATEJ) has maintained in the last 15 years research studies providing a large number of new forms and processes for the integral use of agave.

In short, Mexico has consolidated in recent years to increase exports in the main strategic agrifood products, including: avocado, coffee and cocoa, mainly (ECLAC, FAO, IICA, 2017 , p. 6). However, much remains to be done in the productive chains, in particular, in the drinking of mezcal because those who participate are mostly small producers who live in high marginalization areas whose PP have failed to curb the marginalization, poverty and disarticulation of actions for the welfare of families.

\section{Conclusions}

Public policies in the sector must be aimed at increasing the productivity of the chain in agave and mezcal, in addition, the solutions, programs and strategies need to be transversal in order to face the challenges of social development through actions that improve the quality of life of rural families. Although there are isolated efforts to address the problem from the productive and research fronts, in practice there is evidence of the lack of an operational sector program or plan that involves states with DO and the participation of actors in the Value Chain. In the last two years, important efforts have been made by national forums and tables in the Chamber of Deputies in order to generate a diagnosis of the sector, but above all to build inter-institutional, legislative and linking strategies to enhance the development of the producing regions of coordinated and joint way. However, despite the participation of public instruments of agricultural policy at different levels of government for the production, organization and planning of the sector, there is a lack of coordination and lack of mainstreaming of public policies aimed at solving social, cultural, environmental and economic problems. in the value chain.
This reality requires that in the future multifactorial diagnoses be made, analyze and propose alternatives to comprehensive public policies with the purpose of increasing profitability, productivity, and social improvement of the sector.

As a result of the high increases in mezcal agave, it is currently the small producers who are most interested in increasing the plantation of agaves that can be used in distillation to obtain mezcal in the main producing states with both DO and SDO, although also visualizing the use for others byproducts.

However, they mostly lack the financial resources to do so. Around this reality, there has been a diversification of the producers according to the type of ancestral, artisanal and industrial drinks, packaging machines, exports, consumers and, in general, associated to the Mexican Council for the Quality Regulation of Mezcal (COMERCAM). The main motivation is to improve conditions on the use of the plant, although the most benefited have been the industrial sector and large producers with greater investment and marketing capabilities for the product.

At the local - regional level, it is difficult for municipal governments to transfer the resources necessary to create infrastructure, technology and collaborative networks for access, use, processing and management in the use of information for the design of public policies in the mezcalero sector. It should be noted that there are important (isolated) efforts from research, science and technology for the development of technological projects that seek to respond to socio-productive solutions and improve mezcal production processes in order to generate new opportunities for exploitation. sustainable.

In addition, there is a reduced capacity in the negotiations that small producers have with the sale of their product to marketers due to low volumes of mezcal production and access to convenience stores. Some of the main findings obtained in the field, is that small producers of agave mezcal make clear the lack of knowledge about the existence of public programs aimed at the Value Chain. 
They also highlight that the presence of corruption, impunity and violence that prevails in the country are not foreign to the sector, since the living conditions where they live generate many needs and therefore also said problem (information obtained from personal communication).

Given the lack of coordination of targeted public policies, it is proposed that agricultural policy actions establish objective guidelines and empirical information to guide public policies with a multidisciplinary and interdisciplinary approach, coupled with the great diversity and heterogeneity of the sector. Although there are great advances in internalizing the concepts and methodologies of federal programs with the support of national (public management, academy) and international institutions, in reality there is a disarticulation between government actors and the needs presented by small producers that slow down the promotion of business and entrepreneurship towards foreign trade in the mezcalero sector.

\section{References}

Alvarado A., Vázquez A., Contreras, D. Carmona. Análisis de las políticas públicas del sector mezcalero, para potenciar los negocios y empresarialidad hacia el comercio exterior. Tesis. UTSG-CIATEJ, Guadalajara, México. 2017.

Anderson, J. E. 2006. Public policymaking. Sixth Ed. Cengage Learning.

Comisión Económica para América Latina y el Caribe (CEPAL), Organización de las Naciones Unidas para la Agricultura y la Alimentación (FAO), Instituto Interamericano de Cooperación para la Agricultura (IICA). 2017. Perspectivas de la agricultura y del desarrollo rural en las Américas: una mirada hacia América Latina y el Caribe. San José, C.R.: IICA. URL: https://repositorio.cepal.org/bitstream/handle/11 362/42281/1/PerspAgricultura2017-

2018_es.pdf. [fecha de acceso: 29 de abril de 2018].

Consejo Mexicano Regulador de la Calidad del Mezcal (COMERCAM). 2017. Informe Anual. Oaxaca, México.
Consejo Nacional de Evaluación de la Política de Desarrollo Social (CONEVAL). 2015. Índice de Rezago Social. (Accesado el 10 de mayo de 2019). URL: https://www.coneval.org.mx/Medicion/IRS/Pag inas/Indice_Rezago_Social_2015.aspx.

Consejo Nacional de Población (CONAPO). 2015. Índice de Marginación Municipal 2015. (Accesado el 23/01/2019). URL: http://www.conapo.gob.mx/.

Heyden, D., Camacho, P., Marlin, C., \& Salazar, M. (2004). Guía metodológica para el análisis de cadenas productiva $\mathrm{s}$. Ru ralter para CICDA, SNV e Intercooperation.

Holmlund, M., \& Fulton, M. (1999). Networking for Success: Strategic Alliances in the New Agriculture Centre for the Study of Co-operatives. University of Saskatchewan, and Agriculture Institute of Management in Saskatchewan, Inc.

Holmlund, M., \& Fulton, M. E. (1999). Networking for success: Strategic alliances in the new agriculture (No. 31769). University of Saskatchewan, Centre for the Study of Cooperatives.

Organización de las Naciones Unidas para la Alimentación y la Agricultura (FAO). 2012a. Diagnóstico del sector rural y pesquero de México 2012. (Accesado el 10 de junio de 2017)

URL: http://www.sagarpa.gob.mx/programas2/evalua cionesExternas/Lists/Otros\%20Estudios/Attach ments/47/1\%20Diagn\%C3\%B3stico\%20del\%2 0sector\%20rural\%20y\%20pesquero.pdf.

Organización de las Naciones Unidas para la Alimentación y la Agricultura (FAO). 2012b. Compendio de indicadores estratégicos del sector rural y pesquero.(Accesado el $10 \mathrm{de}$ junio de 2017). URL: http://faoevaluacion.org.mx/cuestionario_final/graficas_ compendio/apps/pdf/compendio_indicadores.pd f.

VÁZQUEZ-ELORZA, Ariel, SANCHEZ-OSORIO, Ever, HERNÁNDEZ-LÓPEZ José de Jesús, CASTAÑEDA-BERNAL Xóchitl Yolanda. Situation of agricultural policy in the sector of agave mezcalero in Mexico, theory and reality. ECORFAN Journal-Republic of Paraguay. 2019. 
Organización de las Naciones Unidas para la Alimentación y la Agricultura (FAO). 2011. GCP/ELS/008/SPA. “Apoyo a la rehabilitación productiva $y$ el manejo sostenible de microcuencas en municipios de Ahuachapán a consecuencia de la tormenta Stan y la erupción del volcán Ilamatepec". (Accesado el 03 de noviembre de 2018). URL: http://www.fao.org/climatechange/30322Of6b6122dbb0e982c1b301f177a745160.pdf.

Plan Nacional de Desarrollo (PND). 20192024. Presidencia de la República. México. (Accesado el 27 de mayo de 2019). URL: https://lopezobrador.org.mx/wpcontent/uploads/2019/05/PLAN-NACIONALDE-DESARROLLO-2019-2024.pdf .

Plan Rector del Sistema Producto Maguey Mezcal en el estado de Oaxaca (PRSPMMO). 2014. Servicio de Información Agroalimentaria y Pesquera-SIAP de la Secretaría de Agricultura, Ganadería, Desarrollo Rural, Pesca y Alimentación-SAGARPA.

Plan Rector Sistema Producto Estatal Maguey Mezcal, Guerrero (PRSPMMG). 2012. Servicio de Información Agroalimentaria y PesqueraSIAP de la Secretaría de Agricultura, Ganadería, Desarrollo Rural, Pesca y Alimentación-SAGARPA.

Porter, M. E. (1985). Competitive advantage: creating and sustaining superior performance. 1985. New York: FreePress.

Red de América. (Accesado el 03 de noviembre de 2018). URL: http://www.redeamerica.org/Noticiadetalle/ArtMID/2470/ArticleID/1064/LasCadenas-Productivas-concepto-elementos-ybarreras.

Sistema Agroalimentario y Pesquero de la Secretaria de Agricultura y Desarrollo Rural de la Secretaria de Agricultura y Desarrollo Rural (SIAP-SADER). 2018. (Accesado el 1 de mayo de 2019). URL: http://www.siap.gob.mx/agriculturaproduccion-anual/.

Tamayo Sáez, M. 1997. El análisis de las políticas públicas. La nueva administración pública, Capítulo 11, pp. 281-312.
Van Der Hieden, D. y Camacho, P. (2004). Guía Metodológica para el análisis de cadenas productivas. RURALTER, SNV, CICDA e Intercooperation. 